\title{
VARIAN FRY: AN ORDINARY AMERICAN WHO MADE A DIFFERENCE
}

\author{
Stephen Kneeshaw \\ College of the Ozarks
}

In the spring of 1945 Allied armies moved into central and eastern Europe from the West and East. Liberation forces marched into German camps with names such as Dachau (in Germany itself) and Auschwitz (in Poland), and the world began to witness up close the horrors of Adolf Hitler's "final solution" for "the Jewish problem." In reality, some people knew about the horrors of the Holocaust before 1945, and a few had put their own lives in jeopardy in their attempts to save Jews and other "undesirables" from certain death at the hands of Hitler's henchmen.

History books often describe the hide-and-seek life that Anne Frank and her family endured in Amsterdam, trying to avoid capture and internment (or even death) in German camps. Thomas Keneally and Steven Spielberg - in book and movieintroduced Oskar Schindler and his "list." Swedish executive and diplomat Raoul Wallenberg used deception, bribery, and "protection passes" to help thousands of Hungarian Jews escape persecution and death in 1944 and 1945-at the expense of his own life. Those stories often get told. Now we need to add other names to the list of people who stepped up to the challenges to civilization that Hitler represented.

Another notable rescuer - and one of a type I sometimes call "everyday people"was an American journalist named Varian Fry, a good example of an ordinary American who did extraordinary things with his life. Born into a "comfortable" middleclass family in New York City, the son of a Wall Street manager and a teacher, at quick glance Fry seemed blessed with the trappings of wealth. For example, he attended school at Hotchkiss and college at Harvard. But he suffered a lonely childhood, burdened with small size, thick glasses, and the name Varian that he thought sounded girlish. He showed little penchant for resistance to authority until the day he resigned from Hotchkiss, a prestigious prep school in Connecticut, to protest hazing of younger students by seniors. But even then he seemed to settle back into routine. ${ }^{2}$

Routine could have swallowed up Varian Fry. Getting a classical education at Harvard, facing a tough job market in the early days of the Great Depression, creating a career in journalism, working with a foreign-policy oriented journal called The Living Age - there is nothing extraordinary to that point in the life of a well-to-do New Yorker.

${ }^{1}$ Thomas Keneally, Schlinder's List (New York: Simon and Schuster, 1982).

${ }^{2}$ The story of Varian Fry's life, from his early years to his passing, appears in many books and websites.
For one book, see Andy Marino, A Quiet American: The Secret War of Varian Fry (New York: St.
Martin's Griffin, 1999), and for a website, see "History of Varian Fry," http://www.almondseed.com/
vfry/fryhist.htm. For a list of "Varian Fry Resources," see http://www.almondseed.com/vfry/fryreso.htm. 
But then he traveled to Berlin in the summer of 1935 on assignment for The Living Age--and he came alive.

At first glance, AdolfHitler's new Berlin looked good with broad boulevards, new roads, and railroads. Then one night in July, Fry witnessed the horrors of an antiJewish riot and he heard the cheering and the chanting: "When Jewish blood spurts from the knife, then things will go even better" cried out the crowd along Kurfurstendamm. ${ }^{3}$ Hitler's new Germany revived old hatreds. Amid the hostility, discrimination, violence, and riots that targeted Jewish-owned businesses, Fry learned about Hitler's plans to exterminate Jews and other undesirables. At that moment, he decided to break from his routine and ordinary life: "I volunteered myself. I remembered what I had seen in Germany." At that moment, he took his first steps to becoming a rescuer.

Through the late 1930s, Fry tried to alert Americans to the horrors building in Europe, but few listened to him. Fry's biographer Andy Marino says he was "a Cassandra uttering unwelcome prophesies to a largely unresponsive nation." " Once Hitler claimed Austria and Czechoslovakia and rolled his armies into Poland, Fry knew that he needed to act as well as speak and write about European events. By early 1940, Fry had affiliated himself with the Emergency Rescue Committee (ERC), and he volunteered to travel to France to help German Jews in France break free from the grips of Hitler's policies of deportation and extermination.

For more than a year, Fry represented the ERC in Marseilles, trying to rescue German Jews in France threatened by Article 19 of the Franco-German armistice of 1940. The "surrender on demand" clause of the agreement called for European Jews in Vichy-controlled France to return to Germany "on demand." What followed for Fry is the stuff of spy and espionage tales. Fry stayed in France even after his American passport expired; he worked with black marketers and forgers to get travel documents; and he arranged the escape of more than 1500 Jews (more than the number on Oskar Schnidler's famous "list"). ${ }^{6}$ All the while Fry was under surveillance by the American FBI, Hitler's Nazis, and Vichy officials. But he stayed "because the refugees needed

${ }^{3}$ Marino, 7.

${ }^{4}$ Fry quoted in http://www.nytimes.com/2001/1 1/24/books/chapters25-1st-isenb-html.

${ }^{5}$ Marino, 26.

${ }^{6}$ Anita Kassof, "Varian Fry and the Emergency Rescue Committee: A Resource Guide for Teachers," The Holocaust Rescue Research Center, http://www.holocaust-trc.org/varian-fry-and-the-emergencyrescue-committee/a-resource-guide-for-teachers/. 
me."7 He returned home in September 1941 when Vichy authorities termed him an "undesirable alien."

The Jewish refugees spirited out of France through Marseilles-transported into neutral Portugal or literally shipped out of France to the United States via Martiniqueincluded some of the brightest lights in European art and culture. To name just a few: Hannah Arendt, a German political theorist and historian; Marc Chagall, a russian Jew by birth, whose surrealist art had flowered in Paris in the 1920s; and Jacques Lipchitz, a Cubist sculptor and colleague of Pablo Picasso, whose artistry continued to damn Hitler's policies and actions long after his arrival in the United States in 1940. ${ }^{9}$

Varian Fry had done well in the short time he worked in Marseilles. But he largely disappeared from view for the next half century, although he continued his efforts through the war years to bring attention to Hitler's growing Holocaust. ${ }^{10} \mathrm{He}$ suffered a reprimand from the United States government and finally died in obscurity in 1967. Once again it seemed Varian Fry had become just another ordinary American.

The last years of the twentieth century witnessed a revival of Varian Fry's heroics and his elevation and recognition from "forgotten hero" to "the American Schindler" and "a hero of our own." "11 France awarded Fry the Legion of Honor in 1967. Perhaps his great honor came in 1995 when Yad Vashem, the Holocaust Heroes and Martyrs Remembrance Authority in Jerusalem, named him the first American "Righteous Among the Nations." That honor set him alongside Oskar Schindler and Raoul Wallenberg to recognize the fact that an ordinary American can do extraordinary things in life.

7"Varian Fry," http://www.almondseed.com/vfry/.

8"History of Varian Fry," http://www.almondseed.com/vfry/fryhist.htm.

${ }^{9}$ See the biographical sketches of these refugees and others that accompany Fry's biography at http://en.wikipedia.org/wiki/Varian_Fry.

${ }^{10}$ See Varian Fry, "The Massacre of Jews in Europe," New Republic (December 21, 1942), and Varian Fry, Surrender on Demand (1945; reprint Boulder, CO: Johnson Books, 1997).

11"Varian Fry," http:/www.almondseed.com/vfry/, uses the "forgotten hero" description. Various sources call Fry "The American Schindler." See "Varian Fry," http://en.wikipedia.org/wiki/Varian_Fry, for one example and for a long list of some of the Europeans he helped rescue. And see Sheila Isenberg, A Hero of Our Own: The Story of Varian Fry (New York: Random House, 2001). 